\title{
Does market access improve dietary diversity and food security? Evidence from Southwestern Ethiopian smallholder coffee producers
}

\author{
Muhammed Abdella Usman * ${ }^{*}$ and Daniel Callo-Concha
}

* Correspondence: mausman25@ gmail.com

Center for Development Research (ZEF), University of Bonn, Genscherallee 3, 53113 Bonn, Germany

\begin{abstract}
Market access influences the dietary diversity and food security for smallholder households in many ways. In Ethiopia, most smallholders are subsistence farmers who have poor access to markets. This study used primary data from a household survey to examine the relationship between market access and the dietary diversity and food security for 324 smallholder households in the Yayu area of southwestern Ethiopia in early 2018. Multivariate regression analysis showed that households located far from market centers consumed not only less diverse foods but also spend less on food consumption than households located close to market centers. The correlation between market access and food security measured by Household Food Insecurity Access Scale (HFIAS) did not reach statistical significance, nor did the impact of market access on household consumption and dietary diversity through income. Rather, greater market access appeared to encourage smallholder households to rely on market purchases more than their own production to improve the diversity of household consumption. A direct action to improve the market accessibility would be investments in infrastructure to expand rural road connectivity, which would reduce transaction costs and benefit the welfare of smallholder farmers and communities.
\end{abstract}

Keywords: Market access, Dietary diversity, Food security, Cash crop, Yayu agroforestry systems, Ethiopia

JEL classifications: $\mathrm{O} 12, \mathrm{O} 13, \mathrm{Q} 18$

\section{Introduction}

Food insecurity and undernutrition rates are high in many Sub-Saharan African countries (UNDP 2012). In addition to compromising wellbeing, undernourishment in early life impairs proper cognitive and physical development, which affects later health outcomes, school performance, and labor productivity in adulthood (Alderman et al. 2006; Glewwe et al. 2001). Globally, around 815 million people were estimated to be chronically undernourished in 2016 (FAO, IFAD, UNICEF, WFP, and WHO 2017). In Ethiopia, about $38 \%$ of children younger than 5 years have stunted growth, defined as

(c) The Author(s). 2021 Open Access This article is licensed under a Creative Commons Attribution 4.0 International License, which permits use, sharing, adaptation, distribution and reproduction in any medium or format, as long as you give appropriate credit to the original author(s) and the source, provide a link to the Creative Commons licence, and indicate if changes were made. The images or other third party material in this article are included in the article's Creative Commons licence, unless indicated otherwise in a credit line to the material. If material is not included in the article's Creative Commons licence and your intended use is not permitted by statutory regulation or exceeds the permitted use, you will need to obtain permission directly from the copyright holder. To view a copy of this licence, visit http://creativecommons.org/licenses/by/4.0/. 
low height for age (CSA and ICF International 2017), which indicates chronic malnutrition.

Agricultural production remains the main source of livelihood for many rural households, and this industry employs over $60 \%$ of the labor force in Sub-Saharan Africa (Thornton et al. 2011). The link between agriculture and security of food and nutrition is, at first sight, straightforward. Paradoxically, most of the poor and undernourished people live in smallholder households, defined as small farms operating within a smallscale model of agriculture (Ogutu et al. 2020). Cultivating diverse crops and raising livestock has a positive dietary effect on the supply of micronutrients to smallholder households. Nevertheless, the empirical evidence that links agriculture and nutrition outcome appears weak (Webb and Kennedy 2014).

The growth in agricultural productivity has done little to improve food and nutrition security of farming households because gains in productivity are mainly from the production of staple foods, such as rice, wheat, and maize, which are crops that provide only a scarce amount of vitamins and minerals (UNDP 2012). Food and nutrition security are influenced not only by the quantity of available food but also by its diversity. As a result, access to healthy, diverse, and affordable food is central to household food security (Ruel et al. 2017). Furthermore, most smallholders sell their staples and buy food items from local markets. Subsequently, identifying and understanding the interactions between agriculture and nutrition is far more complicated than may be assumed.

Smallholders need more than increasing agricultural productivity to ensure a sustained supply of diverse foods and to safeguard their food and nutrition security. Increasing on-farm production diversity is positively associated with greater diversity in household food consumption (e.g., Bellon et al. 2016; Chegere and Stage 2020; Islam et al. 2018; Jones et al. 2014; Muthini et al. 2020; Sibhatu et al. 2015; Singh et al. 2020; Usman and Haile 2019). However, this type of production may not happen if farming income from specialized production outweighs the gains from farming diversification (Sibhatu et al. 2015).

Smallholders face several constraints that prevent them from expanding and diversifying their production beyond the subsistence level. In Ethiopia, most smallholders are located in remote areas; therefore, they are poorly connected to local markets, which results in high transaction costs in terms of buying and selling agricultural products and other goods (Stifel and Minten 2017). Smallholders are also poorly linked to markets because of a lack of information, low production, and low farm-gate prices-prices received by farmers for their produce at the location of a farm (Wiggins and Keats 2013). All these conditions are concomitant in Ethiopia.

Agroforestry is the dominant farming system in southwestern Ethiopia. Farmers produce a variety of food crops, fruits, and vegetables as well as shrubs and trees-some of high value-on the same piece of land (Jemal et al. 2018). Agroforestry systems can be a source of micronutrients and contribute to diversifying household food consumption (Jemal et al. 2018); however, the farming system is dominated by a few high-value cash crops, such as coffee (Coffea arabica) and khat (Catha edulis). This focus may affect own-food crop production because more agricultural resources are freed from staple food production to be used more efficiently for producing cash crops. In turn, smallholder households become less self-sufficient and more dependent on markets. 
Markets offer more diverse foods than any given household can produce (Bellon et al. 2016). Markets also determine the price for agricultural produce and the farmer's revenue, which affects the household consumption expenditures (Stifel and Minten 2017). Previous research showed that smallholders generating income from cash crops spend more money on foods of better quantity (Negash and Swinnen 2013; Pierre-Louis et al. 2007). For example, Negash and Swinnen (2013) found a positive relationship between household food caloric intake and the production of castor beans (Ricinus communis), a species used for biofuel in Ethiopia. In contrast, a study in Vietnam by Janssen (2018) reported that commercialized households spend a larger share of their incomes on non-food items than on food. Taken together, these findings suggest that the effects of income from cash crops on the food access for a smallholder household can be either positive or neutral, depending on the local context.

In this setting, this study aims to understand the extent to which market access contributes to the dietary diversity and food security of smallholder households in the Yayu area of southwestern Ethiopia. To measure food security, the study used the Household Dietary Diversity Score (HDDS) as a proxy for diet quality and the Household Food Insecurity Access Scale (HFIAS) score as proxies for both the behavioral and psychological aspects of insecure food access for the household. The article is structured as follows: "Market access, household dietary diversity and food security" section addresses the links between market access and household consumption and food security. "Materials and methods" section presents the data sampled and the statistical methods for analysis. "Results and discussion" section provides the descriptive and the multivariate regression results and discusses the findings. "Conclusions" section concludes with the implications of the study findings and ad hoc suggestions.

\section{Market access, household dietary diversity, and food security}

Access to markets can increase smallholders' income and improve their food consumption (Abay and Hirvonen 2017; Dercon et al. 2009), and consequently reduce poverty and food insecurity (Pingali 1997). Because food and nutrition security require not only access to a sufficient amount of food but also access to diversified foods, market access can directly contribute to those requirements by increasing the availability and variety of micronutrient-rich foods (e.g., Abay and Hirvonen 2017; Sibhatu et al. 2015; Stifel and Minten 2017; Usman and Haile 2019). Thus, market access can partially substitute for the need to produce diverse food crops to diversify household consumption.

Greater market access can also increase the opportunities for livelihood diversification (Jacoby and Minten 2009) and income generation, which can, in turn, empower the household to purchase a variety of foods from local markets (Sibhatu et al. 2015). In addition, higher incomes allow households to access better healthcare services, which can improve health and nutrition outcomes (von Braun 1995). Better market access also means that smallholders gain faster access to agricultural inputs that induce farm productivity, which results in higher household income (UNDP 2012). In sum, the World Bank (2012) suggests that better market access is central to improving the wellbeing of the rural population in many low- and middle-income countries. 
In a setting in which household consumption and farm production decisions are inseparable due to imperfect input/output markets, decisions about production and consumption are made jointly. Thus, a household's production decision also affects a household's consumption. In one regard, the income from cash crop production can also be used to purchase farm inputs for food crop production that increase productivity and thereby improve food availability (Govereh and Jayne 2003). In another regard, household food consumption may be negatively affected if more agricultural inputs such as land and labor shift away from food crop production (von Braun and Kennedy 1994) because non-cash crop production becomes an inferior income stream for households due to its low financial return. What determines smallholders' priorities in resource allocation and investment decisions also affects the production of other food crops, fruits, and vegetables (Immink and Alarcon 1993). Because food crops and vegetables that provide calories and micronutrients to rural households are produced in limited quantities, market access determines the availability of foods for highly commercialized farm households. Overall, market access may not always translate into enhanced household food and nutrition security because its impact is context-specific (e.g., Linderhof et al. 2019; Ntakyo and van den Berg 2019; Radchenko and Corral 2018; Wood et al. 2013).

The conceptual framework shown in Fig. 1 illustrates the various market pathways through which market can affect household consumption. As shown, the benefits of market access on household dietary diversity and food consumption occur mainly through the availability and diversity of foods, food prices, agricultural productivity, and increasing household income, which may then be used to buy more varieties of foods for household consumption. Accessing food markets is therefore important for farm households engaged in cash crops production.

\section{Materials and methods}

\section{Description of the study area}

This study was carried out in the Yayu Coffee Forest Biosphere Reserve, which is recognized by UNESCO as an in-situ conservation area of wild coffee (Coffea arabica). Yayu

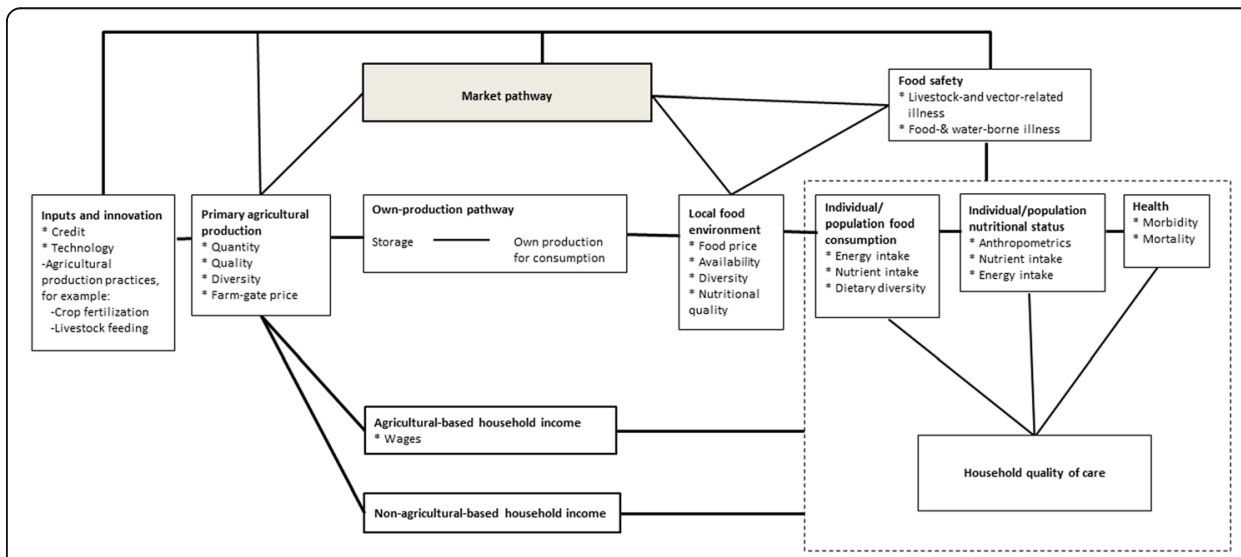

Fig. 1 Conceptual framework of the links between agriculture, the food system, nutrition, and public health. Source: Adopted from Kanter et al. (2015) 
is one of the woreda of the Illubabor Zone, located $500 \mathrm{~km}$ from Addis Ababa, in southwestern Ethiopia. ${ }^{1}$ The study area is situated between $8^{\circ} 0^{\prime} 42^{\prime \prime} \mathrm{N}-8^{\circ} 44^{\prime} 23^{\prime \prime} \mathrm{N}$ latitude and $35^{\circ} 20^{\prime} 31^{\prime \prime} \mathrm{E}-36^{\circ} 18^{\prime} 20^{\prime \prime}$ 'E longitude, and its altitude varies from 1140 to 2562 meters above sea level. The mean monthly temperature varies between 12 and $29{ }^{\circ} \mathrm{C}$, and the annual rainfall ranges from 1400 to $3000 \mathrm{~mm}$ (Fig. 2). Yayu consists mainly of forests, which account for $69 \%$ of its area, and agricultural lands with $26 \%$ of the area; thus agriculture is the main economic activity, and it employs more than $90 \%$ of the labor force (Assefa 2010). Smallholders are mainly engaged in the production of cash crops-typically coffee and khat, as well as staple crops, such as maize, sorghum, and teff.

Data

The study data are from a primary household survey conducted in Yayu in January 2018. The studied households followed a sampling framework of the BiomassWeb project and were selected using a multistage random sampling design (see Jemal et al. 2018, for detailed information on household sample selection). The survey included 4 woredas, 8 kebeles, and 324 smallholder households. A structured questionnaire was used to collect the following socioeconomic and demographic information from selected households: demographic variables, including family size, household head age, sex, and education; information on food consumption and expenditure in the past 7 days; self-reported food security in the past 12 months; non-farm income sources; agricultural production and sales; and pre-defined indicators of market access, such as the households' distance to market centers and distance to tar roads. In compliance with ethical considerations, selected households were consulted about their willingness to participate in the study.

Variables and measurements

Household dietary diversity score (HDDS)

The Household Dietary Diversity Score (HDDS) was constructed based on the consumption of 12 food groups over a recall period of the past 7 days (Swindale and Bilinsky 2006). The pre-defined food groups included the following 12 food groups: (1) cereals; (2) roots and tubers; (3) vegetables; (4) fruits; (5) meat; (6) poultry and offal; (7) eggs; (8) fish and seafood; (9) pulses, legumes and nuts; (10) milk and milk products; (11) oil and fats; (12) sweets, and spices/condiments. However, in Yayu, the maximum number of food groups consumed was 11 because the consumption of fish and seafood group is nonexistent. The study also used the food variety score (FVS) to count the number of food items consumed in the past 7 days before the survey as a dependent variable.

Household food (in)security

The Household Food Insecurity Access Scale (HFIAS) developed by Coates et al. (2007) was used to estimate the household food (in)security. The HFIAS provides a recognized and widely applied food security indicator (e.g., Knueppel et al. 2010; MelgarQuinonez et al. 2006). The perceptions of food security by the household were captured

${ }^{1}$ Administratively, regions in Ethiopia are divided into zones, which are subdivided into administrative units called woreda (district). Each district is further subdivided into the lowest geographic administrative unit, called kebele. 


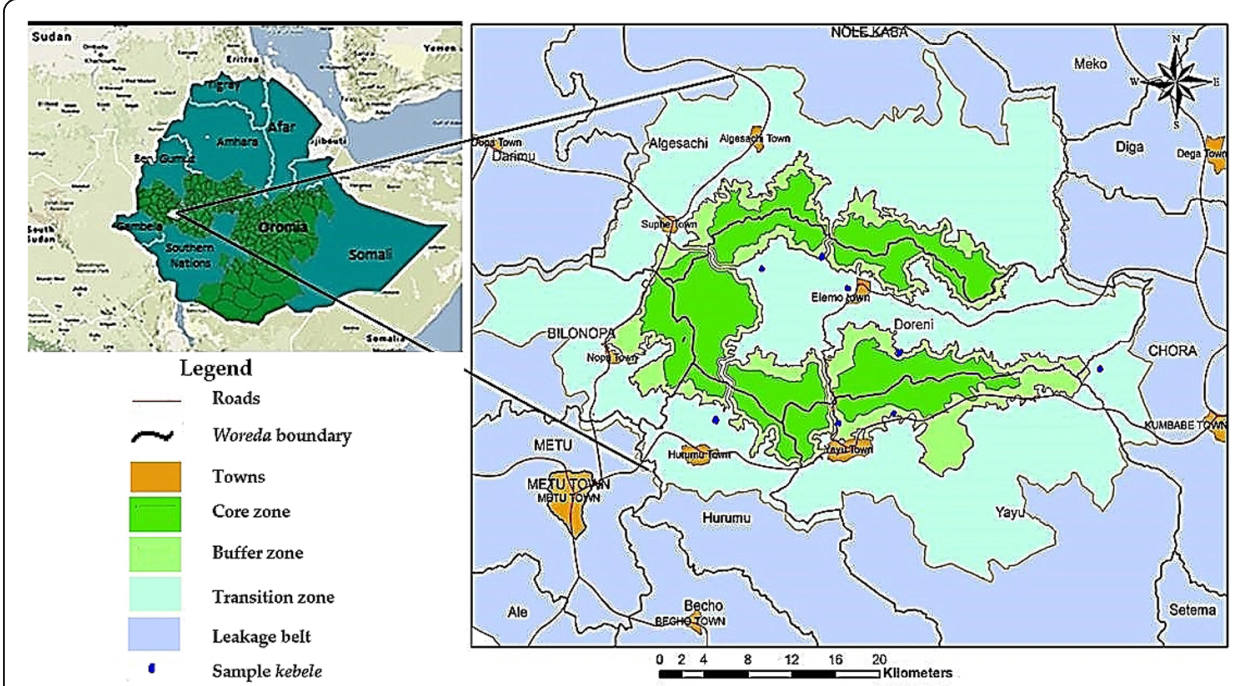

Fig. 2 Location of the study areas and sampled kebeles (geographic administrative units). Source: Gole et al. (2009)

using the standard 9 food security questions, for which the full list is provided in Table 6 in the Appendix. Households are asked if they had experienced any food insecurity issue in the previous 12 months, and if so, how frequent these episodes of food insecurity were. Responses were rated as follows: 0 points if food insecurity did not occur, 1 if it rarely occurred ( 1 or 2 times), 2 if it sometimes occurred ( 3 to 10 times), and 3 if it often occurred (more than 10 times). The total score may range from 0 to 27. Following Kuma et al. (2018), the HFIAS was computed using the total scores and was transformed into a standardized z-score to ease interpretation. ${ }^{2}$ In the multivariate regression models, the study used both, the binary indicator $(=1$ if the household had experienced any food insecurity in the preceding 12 months before the survey; 0 otherwise), and the standardized HFIAS variable.

\section{Market access}

As a proxy for market access, the study used the distance between a household to the nearest market center where the household buys and/or sells food and non-food items. ${ }^{3}$ Households were also asked how much walking-time (in minutes) it takes to reach a given market center and the distance to the nearest tar road in kilometers.

The specific variables included in the multivariate regression analysis were based on theoretical and empirical literature (e.g., Sibhatu et al. 2015; Usman and Haile 2019) and data availability. The models were adjusted for household-level information, including on-farm production diversity, participation in off-farm activities, livestock holding in tropical livestock units (TLUs), farm size, and sociodemographic characteristics that may correlate with consumption diversity and food security as well as market access.

\footnotetext{
${ }^{2}$ The standardized z-scores are constructed by subtracting the household-specific food security value from the sample mean and then dividing this value with the standard deviation of the sample. This approach normalizes the variable with a mean of 0 and standard deviation of 1 .

${ }^{3}$ Four weekly marketplaces were identified in study areas: Wutete, Beteli-Gebecha, Werebo, and Elemo.
} 


\section{Statistical methods}

The study authors are interested in understanding the relationship between market access and household dietary diversity and food (in)security status. The study sought to formalize the relationship between market access and household food consumption based on a reduced farm household model. To model the level of dietary diversity and food security reported by household $i$, a reduced regression model was estimated as follows:

$$
D D_{i}=\beta_{0}+\beta_{1} M_{i}+\beta_{2} X_{i}+\varepsilon_{i}
$$

where $D D_{\mathrm{i}}$ is the outcome of interest (e.g., household dietary diversity score, food security); $M_{\mathrm{i}}$ is access to market indicator (distance or walking time to the nearest market center), $X_{\mathrm{i}}$ represents all other sociodemographic characteristics that could potentially influence dietary diversity and food security status of the households, and $\beta_{1}$ measures the relationship of interest, meaning the effect of market access on the household dietary diversity and food security. The model was estimated using ordinary least squares (for both household dietary diversity and the standardized HFIAS score) and logit (for the binary food insecurity indicator outcome). ${ }^{4}$

\section{Results and discussion}

\section{Descriptive statistics}

The descriptive statistics of the variables are reported in Table 1. Most of the food groups consumed by an average household were purchased from markets. An average household produced 2.96 food groups (6.47 crops and livestock spices), but consumed, on average, 7.49 food groups-implying that the difference between these factors can be attributed to food group purchases. About $53 \%$ of the households experienced food insecurity in the preceding 12 months before the survey. An average household had to travel $4.6 \mathrm{~km}$ to reach the nearest market center for buying or selling agricultural produce. Most of the sample households were disconnected from functioning roads; on average, a given household was $18 \mathrm{~km}$ away from tar/asphalt road. Findings also showed that the level of education was low; the average household head did not complete the primary level of education. Only $11 \%$ of the sample households were female-headed. The average household size was about 5 people, which is comparable to data from a recent study in rural Ethiopia (Usman et al. 2019). Finally, about $44 \%$ of households were engaged in non-farm activities.

Regarding the consumption of specific food groups, Fig. 3 presents the household dietary and production diversity scores (PDS). As shown, households derived a large proportion of their consumption diversity from cereals, vegetables, pulses, legumes and nuts, oil/fat, and spices, all of which were consumed frequently. Milk, milk byproducts, and eggs were the lowest among the food groups consumed. As expected, most food groups, such as roots and tubers, vegetables as well as pulses and legumes, came from market purchases. The survey also indicated that only $7.4 \%$ of sampled households consumed all food groups (11 food groups) in the 7 days preceding the survey. It is,

${ }^{4}$ Although the Poisson model is preferred to ordinary least squares in the case of count outcomes, the study data do not fit well in a Poisson model specification. 
Table 1 Assessed variables and summary statistics for 324 smallholder households

\begin{tabular}{lllll}
\hline Variables & Mean/proportion & SD & Min & Max \\
\hline Dietary diversity and food security & & & & \\
HDDS_food groups & 8.48 & 1.40 & 4.0 & 11.0 \\
HDDS_-purchase food items & 7.29 & 1.40 & 3.0 & 11.0 \\
Food variety score (FVS) & 15.61 & 3.74 & 7.0 & 30.0 \\
FVS with respect to purchase & 11.62 & 3.29 & 4.0 & 25.0 \\
Food insecure-Yes=1 & 0.53 & 0.50 & 0.0 & 1.0 \\
Standardized HFIAS & 0.00 & 1.00 & -0.8 & 3.6 \\
Market access & & & & \\
Distance to market in km & 4.59 & 4.29 & 0.5 & 17.0 \\
Walking time to market in hours & 0.77 & 0.72 & 0.1 & 3.0 \\
Distance to road in km & 18.33 & 17.78 & 0.0 & 45.0 \\
Agriculture characteristics & & & & \\
Production diversity & 6.47 & 2.70 & 0.0 & 16.0 \\
Production diversity score (PDS) & 2.96 & 1.02 & 0.0 & 6.0 \\
Livestock holding in TLUs & 1.85 & 2.50 & 0.0 & 21.4 \\
Farm size & 1.58 & 1.34 & 0.0 & 11.0 \\
Nonfarm activities-Yes = 1 & 0.44 & 0.50 & 0.0 & 1.0 \\
Total agricultural income (1000) & 8.48 & 14.80 & 0.0 & 174.50 \\
Demographic characteristics & & 14.90 & 20.0 & 92.0 \\
Household head age & 4.83 & 0.32 & 0.0 & 14.0 \\
Household head education & 5.11 & 1.88 & 2.0 & 1.0 \\
Female-headed household-Yes & & & & 14.0 \\
Household size & & & & \\
\hline
\end{tabular}

Table 5 in the Appendix provides a detailed description of variable measurement

${ }^{\mathrm{a}}$ Exchange rate during the survey period was 1 Euro $=32$ Ethiopian Birr. More than $96 \%$ of the farmers were involved in the production of coffee

Source: Authors' computation using survey data

however, surprising that the consumption of meat was much higher than the national average for rural households. ${ }^{5}$

The survey showed that about $47 \%$ of the households responded that they were entirely food secure in the past 12 months before the survey because they reported zero incidence of the 9 food insecurity questions (Figure 5 in the Appendix). Thus, the remaining $53 \%$ of the households reported food insecurity in varying degrees, and this result is comparable to that of Kuma et al. (2018). Using the same food security indicator, the study found that about $60 \%$ of the sampled farm households, engaging in the production of cash crops were food insecure.

Figure 4 presents the frequency of the positive responses to the HFIAS questions on the food insecurity situation of the household. More than $50 \%$ of the surveyed households responded that they were not able to eat the kind of food they preferred, and about $47 \%$ said that they had to limit the variety of foods consumed because of lack of

${ }^{5}$ In the recent 2015/16 Living Standards Measurement Study-Integrated Surveys on Agriculture (LSMS-ISA), the consumption of meat among Ethiopian rural households is $30 \%$ lower for the same recall period. This difference could be partially explained by the coincidence between the survey period and a religious celebration in which slaughtering of livestock is common. 


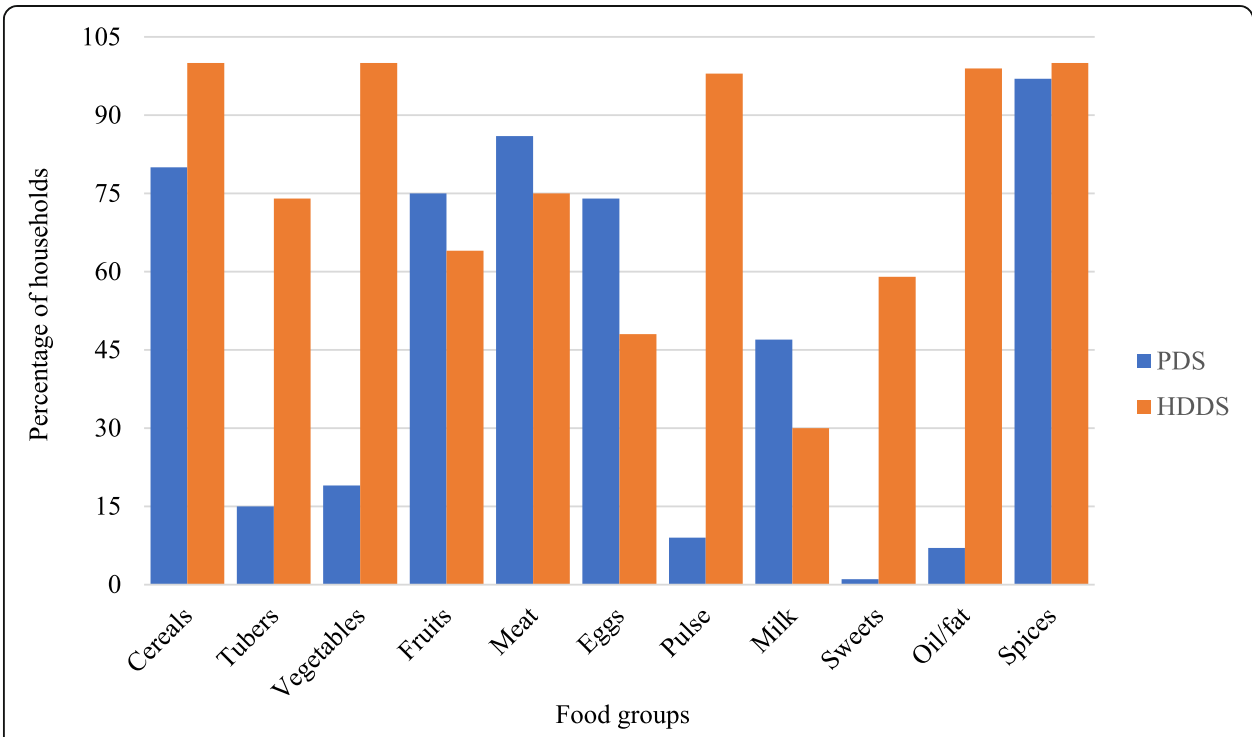

Fig. 3 Production diversity score and last 7 days dietary diversity by studied households. Source: authors' calculations based on survey data

resources. Additionally, around $8 \%$ of the households experienced severe food insecurity, implying that they did not have food to eat on at least one occasion in the 12 months preceding the survey.

\section{Multivariate analysis}

Table 2 summarizes the multivariate regression results of ordinary least squares method, using household dietary diversity score as a dependent variable. The results

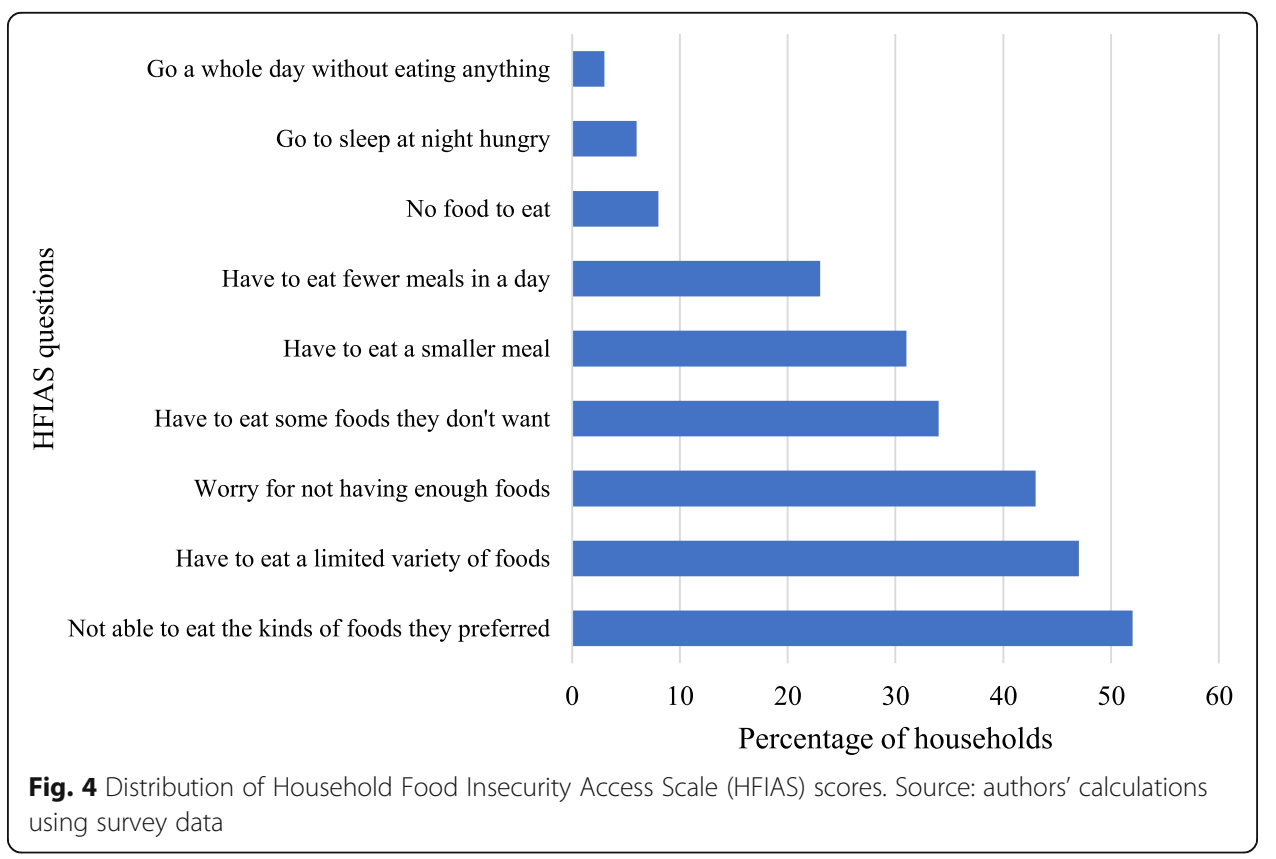


Table 2 Association between market access and HHDS for 324 smallholder households

\begin{tabular}{|c|c|c|c|c|c|c|}
\hline & (1) & (2) & (3) & (4) & (5) & (6) \\
\hline & HDDS & $\begin{array}{l}\text { HDDS } \\
\text { purchased }\end{array}$ & HDDS & $\begin{array}{l}\text { HDDS } \\
\text { purchased }\end{array}$ & HDDS & $\begin{array}{l}\text { HDDS } \\
\text { purchased }\end{array}$ \\
\hline Distance to market & $-0.188^{* * *}(0.069)$ & $-0.397^{* * *}(0.061)$ & & & & \\
\hline $\begin{array}{l}\text { Distance to market } \\
\text { (squared) }\end{array}$ & $0.006(0.004)$ & $0.018^{* * *}(0.004)$ & & & & \\
\hline $\begin{array}{l}\text { Walking time to } \\
\text { markets }\end{array}$ & & & $-1.101^{* * *}(0.381)$ & $-2.245^{* * *}(0.353)$ & & \\
\hline $\begin{array}{l}\text { Walking time to } \\
\text { markets (squared) }\end{array}$ & & & $0.212(0.132)$ & $0.611^{* * *}(0.124)$ & & \\
\hline Distance to a road & & & & & $0.006(0.020)$ & $-0.021(0.020)$ \\
\hline $\begin{array}{l}\text { Distance to a road } \\
\text { (squared) }\end{array}$ & & & & & $-0.000(0.000)$ & $0.000(0.000)$ \\
\hline $\begin{array}{l}\text { Production diversity } \\
\text { score }\end{array}$ & $0.045(0.074)$ & $-0.155^{* *}(0.073)$ & $0.049(0.074)$ & $-0.153^{* *}(0.073)$ & $-0.032(0.076)$ & $-0.288^{* * *}(0.077)$ \\
\hline Farm size & $0.098^{*}(0.050)$ & $0.090 *(0.046)$ & $0.101^{* *}(0.050)$ & $0.087^{*}(0.046)$ & $0.052(0.053)$ & $0.050(0.051)$ \\
\hline $\begin{array}{l}\text { Nonfarm activities- } \\
\text { Yes }=1\end{array}$ & $0.430 * * *(0.150)$ & $0.400^{* * *}(0.145)$ & $0.430 * * *(0.150)$ & $0.416^{* * *}(0.145)$ & $0.563^{* * *}(0.154)$ & $0.637^{* * *}(0.152)$ \\
\hline $\begin{array}{l}\text { Livestock holding in } \\
\text { TLUs }\end{array}$ & $0.107^{* * *}(0.026)$ & $-0.036(0.022)$ & $0.108^{* * *}(0.026)$ & $-0.030(0.022)$ & $0.126^{* * *}(0.026)$ & $-0.002(0.026)$ \\
\hline Household head age & $-0.007(0.006)$ & $-0.009^{*}(0.005)$ & $-0.007(0.006)$ & $-0.009^{*}(0.005)$ & $-0.004(0.006)$ & $-0.006(0.005)$ \\
\hline $\begin{array}{l}\text { Household head } \\
\text { education }\end{array}$ & $0.052^{* *}(0.023)$ & $0.046^{* *}(0.021)$ & $0.052^{* *}(0.023)$ & $0.045^{* *}(0.021)$ & $0.054^{* *}(0.023)$ & $0.041 *(0.022)$ \\
\hline $\begin{array}{l}\text { Female-headed } \\
\text { household- } \\
\text { Yes }=1\end{array}$ & $0.222(0.240)$ & $0.120(0.217)$ & $0.217(0.242)$ & $0.123(0.220)$ & $0.204(0.247)$ & $0.007(0.238)$ \\
\hline Household size & $0.087^{* *}(0.038)$ & $0.075^{* *}(0.035)$ & $0.086^{* *}(0.038)$ & $0.073^{* *}(0.036)$ & $0.072^{*}(0.039)$ & $0.055(0.039)$ \\
\hline Constant & $8.065^{* * *}(0.436)$ & $8.425^{* * *}(0.389)$ & $8.055^{* * *}(0.435)$ & $8.345^{* * *}(0.386)$ & $7.671^{* * *}(0.431)$ & $7.812^{* * *}(0.391)$ \\
\hline R-squared & 0.20 & 0.27 & 0.21 & 0.22 & 0.15 & 0.16 \\
\hline Model F-statistics & 9.549 & 12.265 & 10.009 & 12.462 & 7.405 & 6.249 \\
\hline Model $p$ value & 0.000 & 0.000 & 0.000 & 0.000 & 0.000 & 0.000 \\
\hline
\end{tabular}

indicate that market access is significantly associated with the HDDS across all model specifications, but not when market access is proxied by distance to a road (Table 2, columns 5 and 6). Moreover, the effect of market access increases when assessing HDDS only with respect to the food purchased in the market, suggesting that income is not the only factor that influences household consumption expenditure and/or dietary diversity, but that market infrastructure also plays an essential role. For example, 1 additional kilometer to market is associated with 0.2 units of reduction in the HDDS (Table 2, column 1).

Regarding the control variables, the PDS is significantly associated with HDDS, but the estimated coefficients are negative because the study considered only purchased food groups. Production diversity is however positively correlated with household consumption diversity (Figure 6 in the Appendix). This finding is in line with those of previous studies (e.g., Bellon et al. 2016; Sibhatu et al. 2015; Usman and Haile 2019), asserting that households with diversified on-farm production tend to buy less food to diversify their consumption. As expected, households that own livestock and larger farms have better dietary diversity. Similarly, off-farm activities are significantly correlated with HDDS, which implies that households engaged in off-farm activities consume more diversified diets than households who do not because off-farm income increases the purchasing power of the household to buy more diversified foods from local markets (e.g., Babatunde and Qaim 2010; Islam et al. 2018; 
Rahman and Mishra 2020; Sibhatu et al. 2015; Usman and Haile 2019). The results also showed that HHDS increased marginally with the household size because more and varied household members require more and diverse foods based on their age, sex, and personal preferences. The age of the household head was negatively associated with HHDS, but was statistically significant at the $10 \%$ level for purchased HHDS only. Finally, HDDS was positively related to the household head's level of education and was statistically significant at 5\%. The effects of household head's sex on HDDS were found to be statistically non-significant, although other studies have shown that female-head households are more prone to food insecurity (Kairiza and Kembo 2019; Magaña-Lemus et al. 2016).

Additionally, the study re-estimated the same models using FVS as an outcome variable instead of HDDS, which produced qualitatively similar results (Table 3). For example, a reduction of $1 \mathrm{~h}$ of walking time to the market was associated with a 3-unit increase in the number of food items consumed or the consumption of 4 additional units of purchased food items (Table 3, columns 3 and 4). Unlike the results presented in Table 2, the relationship between household head age and FVS became statistically significant $(p<$ 0.05), implying that an older household head is associated with the consumption of a low number of purchased food items (Table 3). The results also showed that distance to market and household consumption expenditures were negatively associated and statistically significant across all model specifications (Table 7 in the Appendix). The negative relationship between market access and consumption expenditure implies that a household located far away from market centers spends less on food consumption, which in turn, may reduce the diversity of food intake. Indeed, household dietary diversity and food consumption expenditures are closely related (Thorne-Lyman et al. 2010; Usman and Haile 2019). In other words, when markets are not easily accessible, smallholder households are obliged to rely more on their own produce than on market purchases.

The relationship between market access and household food security status through a multivariate regression framework was tested (Table 4). The results indicate that, although consistent, the relationship between market access and household food security was not statistically significant at any conventional level. The study re-estimated the models using HFIAS as a count variable; however, again, the relationship was far from significant (Table 8 in the Appendix). The study further tested the relationship between food consumption score (FCS) and market access. ${ }^{6}$ Although the signs of all the estimated coefficients of market access indicator variables were negative as expected, only the variable of the distance to a road was statistically significant at 1\% (Table 9 in the Appendix). ${ }^{7}$ Finally, the study tested if access to markets has a differential effect on agricultural household income. Results show that market access did not lead to significantly different household income, which indicates that the impact of market access on household consumption and dietary diversity through income is weak.

Households with larger farm sizes, owning livestock, and led by educated household heads, are more likely to be food secure. In contrast, larger households and households

\footnotetext{
${ }^{6}$ The FCS is closely related with HDDS and is considered an indicator of household caloric availability/intake. Using the FCS indicator, the current study shows that more than $96 \%$ of the sampled households were food secure based on the 7-day recall period, whereas the remaining households were at the borderline. ${ }^{7}$ Appendix Figure A3 show the relationship between distance to market in terms of wlaking hours and kilometers.
} 
Table 3 Association between Market Access and Food Variety Score (FVS) for 324 smallholder households

\begin{tabular}{|c|c|c|c|c|c|c|}
\hline & (1) & $(2)$ & (3) & (4) & (5) & (6) \\
\hline & FVS & $\begin{array}{l}\text { FVS } \\
\text { purchased }\end{array}$ & FVS & $\begin{array}{l}\text { FVS } \\
\text { purchased }\end{array}$ & FVS & $\begin{array}{l}\text { FVS } \\
\text { purchased }\end{array}$ \\
\hline $\begin{array}{l}\text { Distance to market, } \\
\mathrm{km}\end{array}$ & $-0.596^{* * *}(0.170)$ & $-0.782^{* * *}(0.144)$ & & & & \\
\hline $\begin{array}{l}\text { Distance to market } \\
\text { (squared) }\end{array}$ & $0.032^{* * *}(0.010)$ & $0.040^{* * *}(0.008)$ & & & & \\
\hline $\begin{array}{l}\text { Walking time to } \\
\text { market, hours }\end{array}$ & & & $-3.094^{* * *}(1.006)$ & $-4.167^{* * *}(0.871)$ & & \\
\hline $\begin{array}{l}\text { Walking time to } \\
\text { market (squared) }\end{array}$ & & & $0.951^{* * *}(0.363)$ & $1.251^{* * *}(0.315)$ & & \\
\hline Distance to road, km & & & & & $-0.065(0.051)$ & $-0.087^{*}(0.047)$ \\
\hline $\begin{array}{l}\text { Distance to a road } \\
\text { (squared) }\end{array}$ & & & & & $0.001(0.001)$ & $0.001(0.001)$ \\
\hline $\begin{array}{l}\text { Production diversity } \\
\text { score }\end{array}$ & $0.260(0.214)$ & $-0.476^{* *}(0.192)$ & $0.263(0.215)$ & $-0.474^{* *}(0.193)$ & $0.084(0.217)$ & $-0.722^{* * *}(0.194)$ \\
\hline Farm size & $0.365^{* *}(0.157)$ & $0.299^{* *}(0.124)$ & $0.371^{* *}(0.157)$ & $0.300^{* *}(0.125)$ & $0.348^{* *}(0.152)$ & $0.263^{* *}(0.127)$ \\
\hline $\begin{array}{l}\text { Nonfarm activities- } \\
\text { Yes=1 }\end{array}$ & $1.097^{* * *}(0.403)$ & $1.159^{* * *}(0.341)$ & $1.136^{* * *}(0.405)$ & $1.207^{* * *}(0.342)$ & $1.398^{* * *}(0.413)$ & $1.570^{* * *}(0.353)$ \\
\hline $\begin{array}{l}\text { Livestock holding in } \\
\text { TLUs }\end{array}$ & $0.320^{* * *}(0.089)$ & $0.115(0.092)$ & $0.326^{* * *}(0.089)$ & $0.126(0.093)$ & $0.365^{* * *}(0.101)$ & $0.180^{*}(0.108)$ \\
\hline Household head age & $-0.016(0.016)$ & $-0.025^{* *}(0.012)$ & $-0.016(0.016)$ & $-0.025^{* *}(0.012)$ & $-0.015(0.016)$ & $-0.023^{*}(0.012)$ \\
\hline $\begin{array}{l}\text { Household head } \\
\text { education }\end{array}$ & $0.134^{* *}(0.062)$ & $0.076(0.056)$ & $0.131 * *(0.062)$ & $0.073(0.056)$ & $0.111 *(0.061)$ & $0.049(0.055)$ \\
\hline $\begin{array}{l}\text { Female-headed } \\
\text { household-Yes=1 }\end{array}$ & $0.439(0.600)$ & $0.354(0.483)$ & $0.433(0.611)$ & $0.353(0.495)$ & $0.145(0.643)$ & $-0.017(0.516)$ \\
\hline Household size & $0.147(0.110)$ & $0.165^{*}(0.092)$ & $0.146(0.110)$ & $0.163^{*}(0.092)$ & $0.134(0.110)$ & $0.144(0.091)$ \\
\hline Constant & $14.061 * * *(1.123)$ & $13.767^{* * *}(0.957)$ & $13.854^{* * *}(1.125)$ & $13.523^{* * *}(0.960)$ & $13.666^{* * *}(1.161)$ & $13.187^{* * *}(0.983)$ \\
\hline R-squared & 0.17 & 0.22 & 0.17 & 0.21 & 0.16 & 0.19 \\
\hline Model F-statistics & 5.496 & 7.237 & 5.339 & 6.637 & 5.346 & 5.625 \\
\hline Model- $p$ value & 0.000 & 0.000 & 0.000 & 0.000 & 0.000 & 0.000 \\
\hline
\end{tabular}

Robust standard errors are in parentheses; statistical significance is ${ }^{*} p<0.10,{ }^{* *} p<0.05,{ }^{* * *} p<0.01$

engaged in non-farm activities are, on average, more likely to be food insecure. The negative effect of non-farm activities on food security is counterintuitive. Households engaged in non-farm activities are expected to be more resilient and food secure because the extra income would have meant an improvement in their food access (Babatunde and Qaim 2010; Do et al. 2019). However, because off-farm income was measured as a dummy variable in this study, it does not reflect the actual level of income generated. Additionally, these data show that land-scarce households were $34 \%$ more likely to look for jobs outside agriculture ( $p<0.01$, for a bivariate regression). Another possible explanation could be that the income generated from non-farm activities may not be spent in a way that enhances household food security, and that non-farm activities may reduce agricultural productivity due to labor constraints. The variable may also suffer from recall bias because the time horizon used was 12 months.

Altogether, the study results indicate that households located closer to markets not only spend more on food but also consume more diversified foods than households located far away from markets. For smallholders, whose income is mainly generated from selling agroforestry products such as coffee and Khat (Figure 8 in the Appendix), onfarm diversification may not be an efficient way to diversify their diets because they may not be able to produce all the food items that they require due to the limited resource endowments, such as land. Therefore, improving market access could be important for 
Table 4 Association between market access and food security for 324 smallholder households

\begin{tabular}{|c|c|c|c|c|c|c|}
\hline & (1) & (2) & (3) & (4) & (5) & (6) \\
\hline & $\begin{array}{l}\text { Food } \\
\text { insecurity- } \\
\text { Yes }=1\end{array}$ & $\begin{array}{l}\text { Standardized } \\
\text { HFIAS }\end{array}$ & $\begin{array}{l}\text { Food } \\
\text { insecurity- } \\
\text { Yes }=1\end{array}$ & $\begin{array}{l}\text { Standardized } \\
\text { HFIAS }\end{array}$ & $\begin{array}{l}\text { Food } \\
\text { insecurity- } \\
\text { Yes = } 1\end{array}$ & $\begin{array}{l}\text { Standardized } \\
\text { HFIAS }\end{array}$ \\
\hline Distance to market & $1.191(0.141)$ & $-0.004(0.049)$ & & & & \\
\hline $\begin{array}{l}\text { Distance to market } \\
\text { (squared) }\end{array}$ & $0.996(0.007)$ & $0.001(0.003)$ & & & & \\
\hline $\begin{array}{l}\text { Walking time to } \\
\text { market }\end{array}$ & & & $2.345(1.596)$ & $-0.098(0.289)$ & & \\
\hline $\begin{array}{l}\text { Walking time to } \\
\text { market (squared) }\end{array}$ & & & $0.918(0.222)$ & $0.072(0.100)$ & & \\
\hline Distance to road & & & & & $1.027(0.036)$ & $0.017(0.016)$ \\
\hline $\begin{array}{l}\text { Distance to a road } \\
\text { (squared) }\end{array}$ & & & & & $1.000(0.001)$ & $-0.000(0.000)$ \\
\hline $\begin{array}{l}\text { Production diversity } \\
\text { score }\end{array}$ & $1.022(0.123)$ & $0.063(0.056)$ & $1.028(0.123)$ & $0.065(0.056)$ & $1.143(0.135)$ & $0.079(0.053)$ \\
\hline Farm size, ha & $0.824^{*}(0.083)$ & $-0.098^{* * *}(0.037)$ & $0.823^{*}(0.083)$ & $-0.100^{* * *}(0.037)$ & $0.881(0.084)$ & $-0.092^{* *}(0.037)$ \\
\hline $\begin{array}{l}\text { Nonfarm activities- } \\
\text { Yes=1 }\end{array}$ & $1.631 *(0.442)$ & $0.229 * *(0.113)$ & $1.596 *(0.427)$ & $0.224^{* *}(0.114)$ & $1.421(0.369)$ & $0.218^{* *}(0.108)$ \\
\hline $\begin{array}{l}\text { Livestock holding in } \\
\text { TLUs }\end{array}$ & $0.889(0.066)$ & $-0.045^{* *}(0.022)$ & $0.889(0.066)$ & $-0.045^{* *}(0.022)$ & $0.861^{* *}(0.061)$ & $-0.052^{* *}(0.023)$ \\
\hline Household head age & $1.016^{*}(0.009)$ & $0.001(0.004)$ & $1.016^{*}(0.009)$ & $0.001(0.004)$ & $1.013(0.009)$ & $0.001(0.004)$ \\
\hline $\begin{array}{l}\text { Household head } \\
\text { education }\end{array}$ & $0.782^{* * *}(0.033)$ & $-0.078^{* * *}(0.015)$ & $0.783^{* * *}(0.033)$ & $-0.078^{* * *}(0.015)$ & $0.787^{* * *}(0.032)$ & $-0.080^{* * *}(0.015)$ \\
\hline $\begin{array}{l}\text { Female-headed } \\
\text { household-Yes = } 1\end{array}$ & $0.607(0.237)$ & $0.061(0.182)$ & $0.617(0.242)$ & $0.066(0.182)$ & $0.683(0.278)$ & $0.068(0.187)$ \\
\hline Household size & $1.235^{* * *}(0.087)$ & $0.106^{* * *}(0.034)$ & $1.237^{* * *}(0.087)$ & $0.106^{* * *}(0.034)$ & $1.257^{* * *}(0.090)$ & $0.108^{* * *}(0.033)$ \\
\hline Pseudo (R-squared) & 0.17 & 0.16 & 0.17 & 0.16 & 0.15 & 0.16 \\
\hline Model F-statistic & & 7.33 & & 7.38 & & 6.82 \\
\hline Model chi-squared & 65.52 & & 64.75 & & 60.72 & \\
\hline Model $p$ value & 0.000 & 0.000 & 0.000 & 0.000 & 0.000 & 0.000 \\
\hline
\end{tabular}

Robust standard errors are in parentheses; statistical significance is ${ }^{*} p<0.10,{ }^{* *} p<0.05,{ }^{* * *} p<0.01$. Coefficients in columns 1,3 , and 5 are odds ratios. The constant term is omitted

promoting dietary diversification and also in helping farmers to be paid better prices for their produce (Abu et al. 2016; Haile et al. 2015). Previous studies have also shown that households located closer to markets are less dependent on their own production and consume more diverse diets (Abay and Hirvonen 2017), and they are also able to smooth their consumption patterns during the lean seasons (Handa and Mlay 2006). ${ }^{8}$ The effects of market access on household food consumption may, however, depend on who controls the income generated through increased market access.

This study has limitations. The data collection period was during January 2018, which is right after the harvesting period (usually October through November). During the harvesting period, households largely depend on their own produce (Hirvonen et al. 2016), so the impact of market access on household consumption may be low (Abay and Hirvonen 2017). The study findings should, therefore, be taken with caution, because households may rely more on market purchases in the lean season. Of note, June, July, and August were the months in which most households did not have sufficient food provision in the past 12 months before the survey (Figure 9 in the Appendix).

\footnotetext{
${ }^{8}$ Consumption smoothing is a mechanism to maintain a stable path of consumption from periods of high income to periods of low income.
} 


\section{Conclusions}

Using primary household survey data collected in Yayu, southwestern Ethiopia, this study aimed to discover the association between market access and householder dietary diversity and food security. The results show that, although the majority of households consumed relatively diverse diets, households located closer to marketplaces had much better dietary diversity and food consumption expenditure than those located far away from markets. Furthermore, the effect of the market on household consumption through income appeared to be trivial. A direct action to improve the market accessibility would be investing in infrastructure to improve rural road connectivity and transportation, which would reduce transaction costs and likely improve the consumption of diversified food among smallholder farmers.

The findings suggest that market access neither significantly improves the household's income nor that the increased income enhanced household dietary diversity. Instead, it appears that market access reduces transaction cost (time) for the households, which encourages them to rely more on market purchases so that they can access more diversified foods, specifically because markets provide more diverse foods than a given individual household can produce. The findings should be interpreted with caution, however, because the study did not consider seasonality, which may bias estimate of the relationships between market access and household consumption and/or dietary diversity.

\section{Appendix}

Table 5 Study variable definitions and measurements

\begin{tabular}{|c|c|}
\hline Variables & Description \\
\hline HDDS—food groups & Household dietary diversity score based on the standard 12 food groups \\
\hline HDDS—purchase food groups & $\begin{array}{l}\text { Household dietary diversity score based on the standard } 12 \text { food groups with respect to } \\
\text { purchased food items only }\end{array}$ \\
\hline Food variety score (FVS) & Number of food items consumed in the past 7-days before the survey \\
\hline FVS - with respect to purchase & $\begin{array}{l}\text { Number of food items consumed in the past 7-days before the survey with respect to } \\
\text { purchased food items only }\end{array}$ \\
\hline Food insecurity & $\begin{array}{l}\text { Equal to } 1 \text { if the household had experienced any food insecurity issues in the preceding } 12 \\
\text { months before the survey }\end{array}$ \\
\hline HFIAS & Household food insecurity access scale based on the standard nine food security questions \\
\hline Distance to market & Distance to the closer market where a household buys and sells agricultural products in kilometers \\
\hline Walking time to market & Distance to the closer market where a household buys and sells agricultural produces in waking hours \\
\hline Distance to road & Distance to the closer asphalt road to a given household in kilometers \\
\hline Production diversity & Number of crop and livestock units produced by the households in the previous harvesting period \\
\hline Production diversity score (PDS) & Number of crops and livestock groups a household cultivate/rear in the previous harvesting period \\
\hline Livestock holdings & Livestock holding in Tropical Livestock Units \\
\hline Farm size & $\begin{array}{l}\text { Total agricultural land size in hectare cultivated by the household in the last harvesting season } \\
\text { before the survey }\end{array}$ \\
\hline Non-farm activities & $\begin{array}{l}\text { Equal to } 1 \text { if any household members of the household have generated income from non-farm } \\
\text { activities in the preceding } 12 \text { months before the survey }\end{array}$ \\
\hline Total agricultural income (1000) & Total household income from agriculture in the current production season in Ethiopian Birr \\
\hline Household head age & Household head age in years \\
\hline Household head education & Household head years of education \\
\hline Household size & Total household members living together \\
\hline
\end{tabular}


Table 6 Questions in the food security module of the survey. We would like to ask you the food security situation of your household during the past 12 months

\begin{tabular}{|c|c|c|c|c|}
\hline & & 1 & 2 & 3 \\
\hline No & In the past 12 months, & $\begin{array}{l}1=Y E S \\
2=N O \\
\text { next }\end{array}$ & $\begin{array}{l}\text { How often did this } \\
\text { happen in the past } 12 \\
\text { months? } \\
1=\text { Rarely (1-2 times) } \\
2=\text { Sometimes (3-10) } \\
3=\text { Often (more than } 10 \\
\text { times) }\end{array}$ & $\begin{array}{l}\text { In which months did your } \\
\text { household experience hunger } \\
\text { period? } \\
\text { Write the name of the } \\
\text { months }\end{array}$ \\
\hline 1 & $\begin{array}{l}\text { Did you worry that your household would not have enough } \\
\text { food? }\end{array}$ & & & \\
\hline 2 & $\begin{array}{l}\text { Were you or any household members not able to eat the kind } \\
\text { of foods you preferred because of lack of resources? }\end{array}$ & & & \\
\hline 3 & $\begin{array}{l}\text { Did you or any household members have to eat a limited } \\
\text { variety of foods because of lack of resources? }\end{array}$ & & & \\
\hline 4 & $\begin{array}{l}\text { Did you or any household member have to eat some foods } \\
\text { that you really did not want to eat because of a lack of } \\
\text { resources to obtain other types of foods? }\end{array}$ & & & \\
\hline 5 & $\begin{array}{l}\text { Did you or any household member have to eat a smaller meal } \\
\text { than you felt you needed because there was not enough food? }\end{array}$ & & & \\
\hline 6 & $\begin{array}{l}\text { Did you or any household member have to eat fewer meals in } \\
\text { a day because there was not enough food? }\end{array}$ & & & \\
\hline 7 & $\begin{array}{l}\text { Was there ever no food to eat at all in your household because } \\
\text { there were no resources to get any food? }\end{array}$ & & & \\
\hline 8 & $\begin{array}{l}\text { Did you or any household member go to sleep at night hungry } \\
\text { because there was not enough food? }\end{array}$ & & & \\
\hline 9 & $\begin{array}{l}\text { Did you or any household member go a whole day without } \\
\text { eating anything because there was not enough food? }\end{array}$ & & & \\
\hline
\end{tabular}

Table 7 Association between household food expenditure and market access for 324 smallholder households

\begin{tabular}{llll}
\hline & (1) Model & (2) Model & (3) Model \\
\hline Distance to market, km & $-0.111^{* * *}(0.029)$ & & \\
Distance to market (squared) & $0.006^{* * *}(0.002)$ & & \\
Walking time to market & & $-0.581^{* * *}(0.164)$ & \\
Walking time market (squared) & & $0.200^{* * *}(0.059)$ & \\
Distance to road, km & & & $-0.040^{* * *}(0.008)$ \\
Distance to a road (squared) & & $-0.017(0.032)$ & $-0.001^{* *}(0.000)$ \\
Production diversity score & $-0.017(0.032)$ & $0.068^{* * *}(0.025)$ & $0.070^{* * *}(0.021)$ \\
Farm size & $0.069^{* * *}(0.024)$ & $0.149^{* *}(0.067)$ & $0.187^{* * *}(0.061)$ \\
Nonfarm activities-Yes $=1$ & $0.140^{* *}(0.068)$ & $0.014(0.012)$ & $0.027^{*}(0.015)$ \\
Livestock holding in TLUs & $0.012(0.012)$ & $-0.003(0.002)$ & $-0.004^{*}(0.002)$ \\
Household head age & $-0.003(0.002)$ & $0.015(0.009)$ & $0.005(0.009)$ \\
Household head education & $0.015(0.009)$ & $-0.002(0.109)$ & $-0.122(0.107)$ \\
Female-headed household-Yes $=1$ & $-0.003(0.109)$ & $0.081^{* * *}(0.020)$ & $0.083^{* * *}(0.017)$ \\
Household size & $0.081^{* * *}(0.020)$ & 324 & 324 \\
Observations & 324 & 0.17 & 0.28 \\
R-squared & 0.18 & 7.327 & 11.601 \\
Model F-stat & 7.677 & 0.000 & 0.000 \\
Model- $p$ value & 0.000 & &
\end{tabular}

Robust standard errors are in parentheses; statistical significance is ${ }^{*} p<0.10,{ }^{* *} p<0.05,{ }^{* * *} p<0.01$ 
Table 8 Association between market access and food security: HFIAS scores for 324 smallholder households

\begin{tabular}{llll}
\hline & $\mathbf{( 1 )}$ & $\mathbf{( 2 )}$ & $\mathbf{( 3 )}$ \\
& Model & Model & Model \\
\hline Distance to market & $1.002(0.061)$ & & \\
Distance to market (squared) & $1.001(0.003)$ & & \\
Walking time to market & & $0.947(0.348)$ & \\
Walking time to market (squared) & & $1.062(0.132)$ & $1.026(0.021)$ \\
Distance to road & & & $0.999(0.000)$ \\
Distance to a road (squared) & & & Yes \\
Other controls & Yes & Yes & 0.14 \\
R-squared & 0.14 & 0.14 & 80.602 \\
Model chi-squared & 81.537 & 82.439 & 0.000 \\
Model $p$ value & 0.000 & 0.000 & \\
\hline
\end{tabular}

Robust standard errors are in parentheses; statistical significance is ${ }^{*} p<0.10,{ }^{* *} p<0.05$, ${ }^{* * *} p<0.01$. Coefficients are given as an incidence rate ratio

Table 9 Association between Market Access and Food Consumption Score (FCS) for 324 smallholder households

\begin{tabular}{llll}
\hline & (1) & (2) & (3) \\
& Model & Model & Model \\
\hline Distance to market, km & $-0.172(0.486)$ & & \\
Distance to market (squared) & $-0.007(0.028)$ & & \\
Walking time to market, hours & & $-0.659(2.806)$ & \\
Walking time market (squared) & & $-0.437(0.987)$ & $-0.484^{* * *}(0.151)$ \\
Distance to road, km & & & $0.011^{* * *}(0.004)$ \\
Distance to the road (squared) & & & Yes \\
Other controls & Yes & Yes & 0.19 \\
R-squared & 0.17 & 0.17 & 5.097 \\
Model F-statistic & 4.314 & 4.633 & 0.000 \\
Model $p$ value & 0.000 & 0.000 & \\
\hline
\end{tabular}

Robust standard errors are in parentheses; statistical significance is ${ }^{*} p<0.10,{ }^{* *} p<0.05,{ }^{* * *} p<0.01$ 


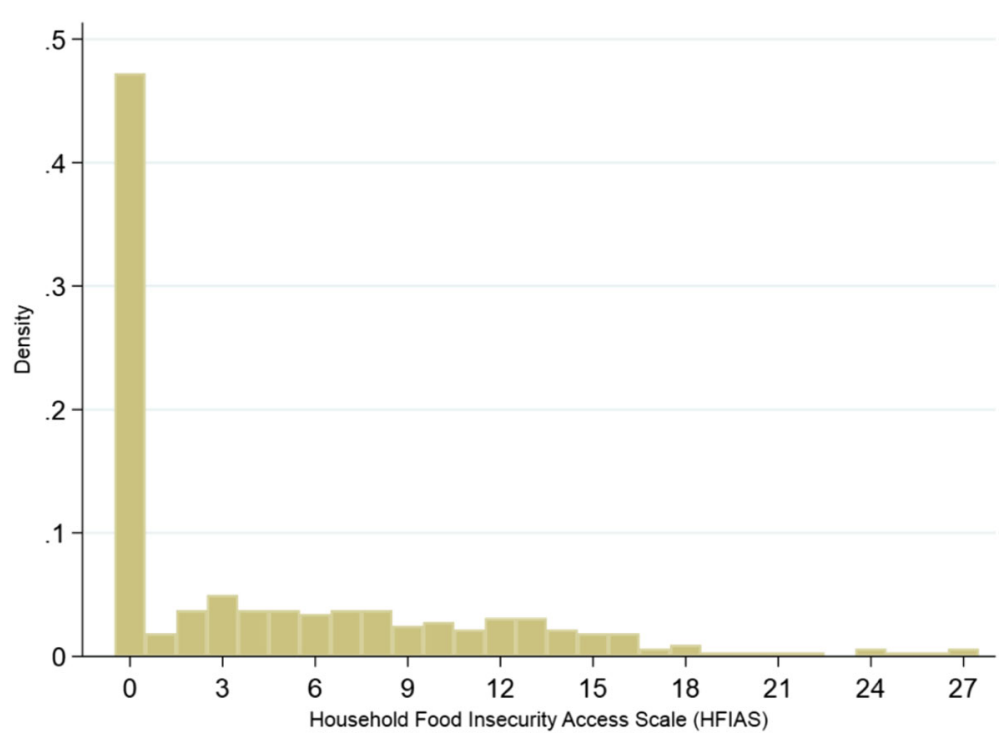

Fig. 5 Distribution of Household Food Insecurity Access Scale (HFIAS) scores. Source: Authors' computation using study survey data

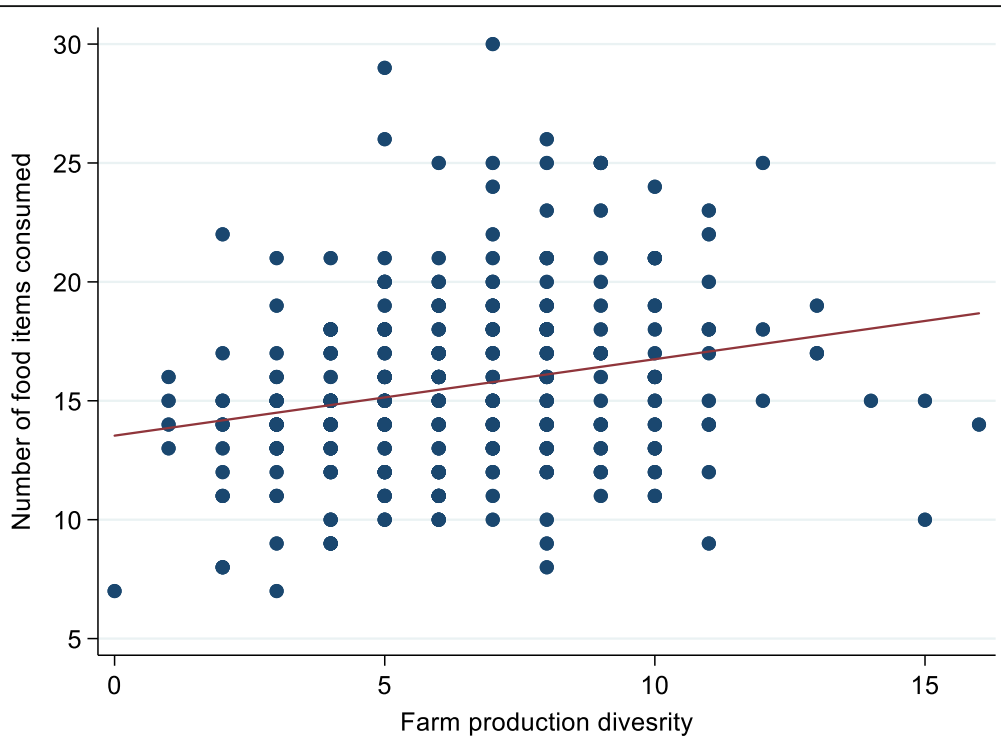

Fig. 6 Relationship between farm production diversity and household dietary diversity. Source: Authors' computation using study survey data 


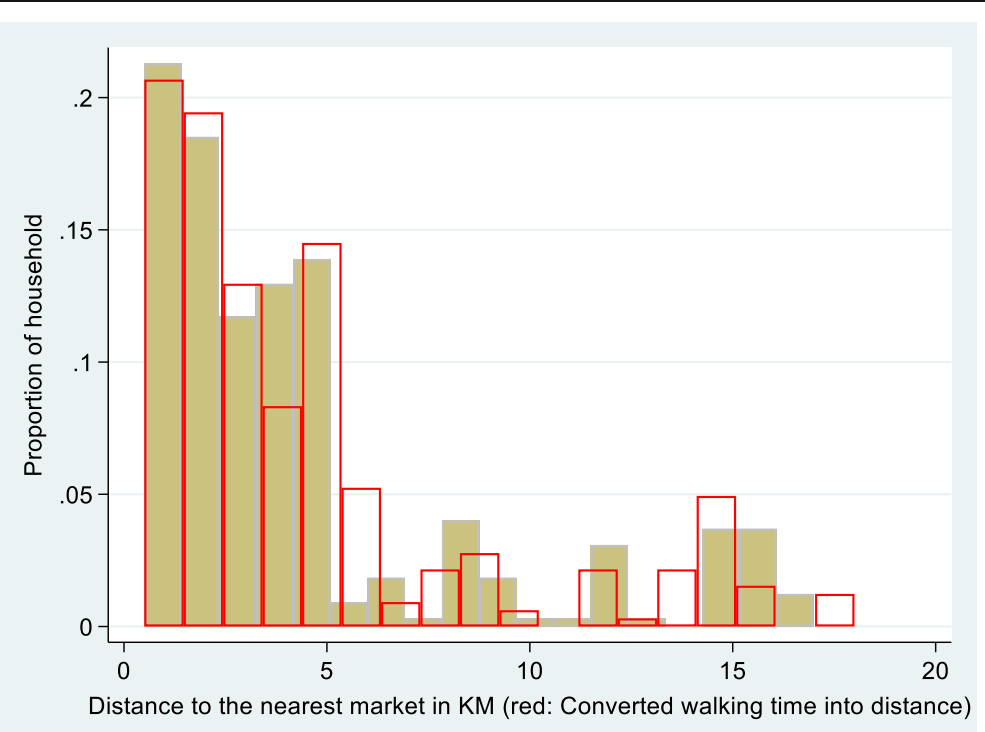

Fig. 7 Distances to markets are measured by both distance and time. Source: Authors' computation using study survey data

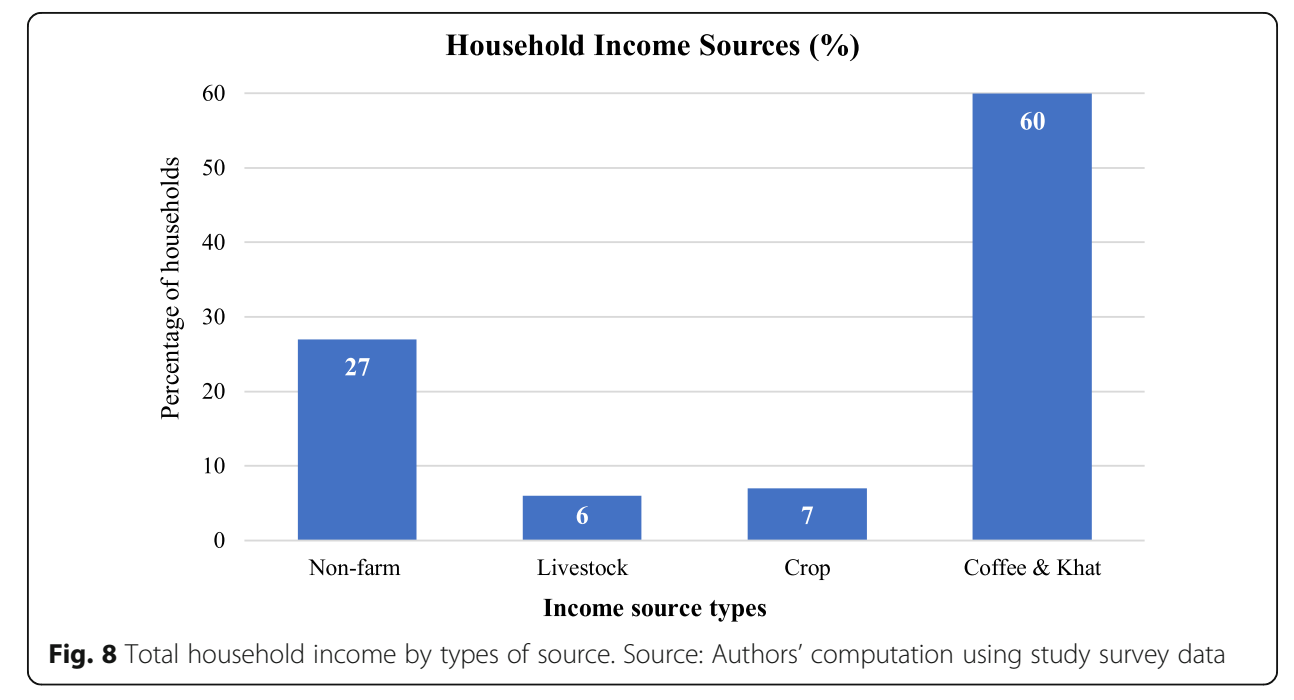




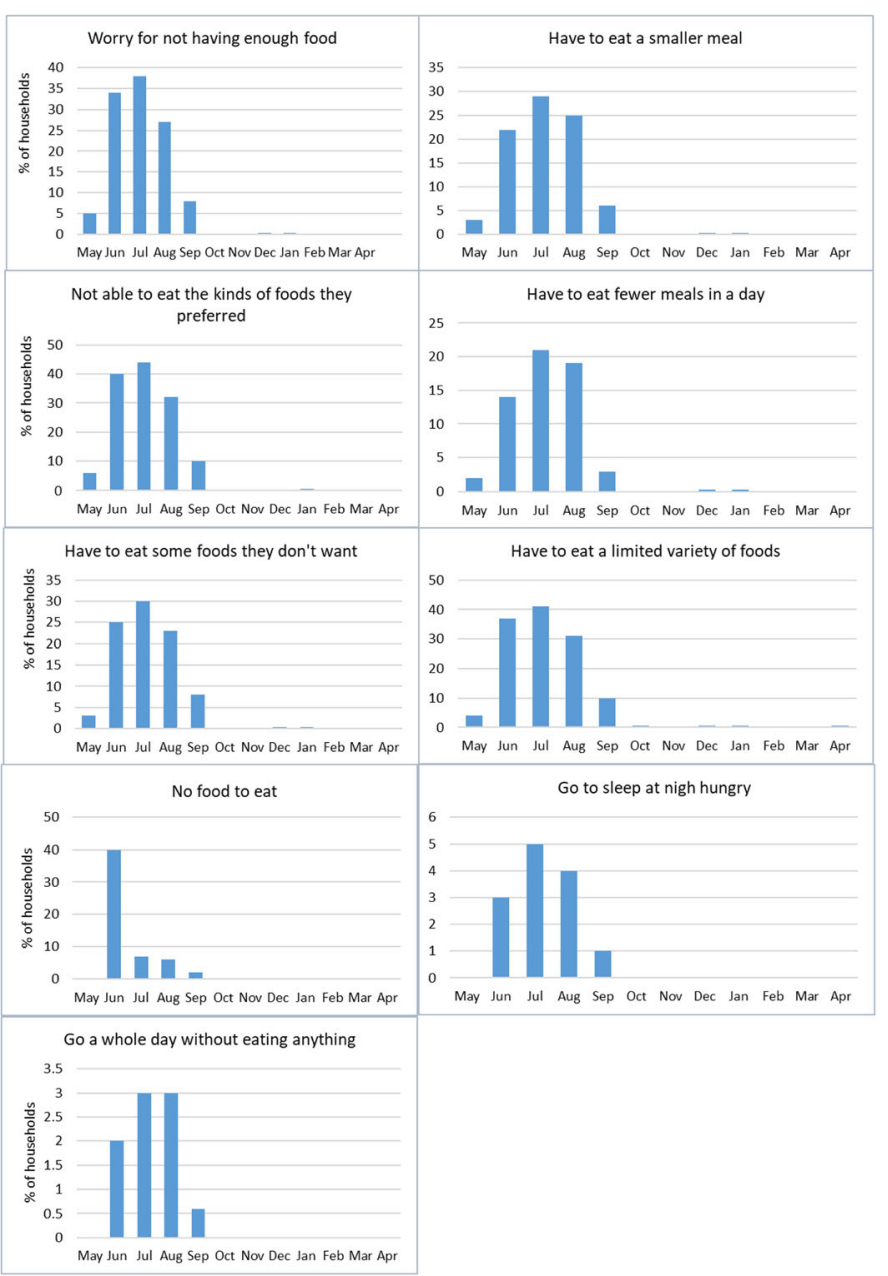

Fig. 9 Months of inadequate household food provisioning. Source: Authors' computation using study survey data

\section{Abbreviations}

CSA: Central Statistical Agency; FAO: Food and Agriculture Organization; FCS: Food Consumption Score; FVS: Food variety score; HDDS: Household Dietary Diversity Score; HFIAS: Household Food Insecurity Access Scale;

PDS: Production Diversity Score; UNDP: United Nations Development Programme; UNESCO: The United Nations Educational, Scientific and Cultural Organization

\section{Acknowledgements}

We are grateful to Dr. Omarsherif Jemal, Mr. Habtamu Aragaw, ECFF (Environment and Coffee Forest Forum), and the Agricultural offices of Yayu and the surrounding Woredas, for their support and facilitation to realize the fieldwork. We thank Rebecca T (Enago, Crimson Interactive Inc.) for English editing the manuscript.

\section{Authors' contributions}

MU conceived the study, conducted the fieldwork, drafted the manuscript, and performed part of the econometrics analysis. DCC contributed to developing the concept note and revising the manuscript. Both authors have read and agreed to the published version of the manuscript.

\section{Funding}

This research was funded by the German Federal Ministry of Education and Research (BMBF) and the Ministry of Economic Cooperation and Development (BMZ) [Grant number: FKZ 031A258A-I]. Open Access funding enabled and organized by Projekt DEAL.

\section{Availability of data and materials}

The datasets used and/or analyzed during the current study are available from the corresponding author on reasonable request. 


\section{Declarations}

\section{Competing interests}

The authors declare that they have no competing interests.

Received: 18 October 2019 Revised: 11 February 2021

Accepted: 15 April 2021 Published online: 06 July 2021

\section{References}

Abay K, Hirvonen K (2017) Does market access mitigate the impact of seasonality on child growth? Panel data evidence from northern Ethiopia. J Dev Stud 53(9):1414-1429. https://doi.org/10.1080/00220388.2016.1251586

Abu BM, Issahaku H, Nkegbe PK (2016) Farmgate versus market centre sales: a multi-crop approach. Agric Food Econ 4(1):21. https://doi.org/10.1186/s40100-016-0065-6

Alderman H, Hoddinott J, Kinsey B (2006) Long term consequences of early childhood malnutrition. Oxford Econ Papers 58(3):450-474. https://doi.org/10.1093/oep/gpl008

Assefa AD (2010) Local institutions and their influence on forest resource management in Southwest of Ethiopia: The Case of Yayu Forest. Addis Ababa University School of Graduate Studies, Addis Ababa Available at: http://etd.aau.edu.et/bitstrea m/123456789/1591/3/Andnet\%20Deresse.pdf

Babatunde RO, Qaim M (2010) Impact of off-farm income on food security and nutrition in Nigeria. Food Policy 35(4):303311. https://doi.org/10.1016/j.foodpol.2010.01.006

Bellon MR, Ntandou-Bouzitou GD, Caracciolo F (2016) On-farm diversity and market participation are positively associated with dietary diversity of rural mothers in Southern Benin, West Africa. PloS One 11(9):e0162535. https://doi.org/10.1371/ journal.pone.0162535

Chegere MJ, Stage J (2020) Agricultural production diversity, dietary diversity and nutritional status: panel data evidence from Tanzania. World Dev 129:104856. https://doi.org/10.1016/j.worlddev.2019.104856

Coates J, Swindale A, Bilinsky P (2007) Household Food Insecurity Access scale (HFIAS) for measurement of household food access: indicator Guide (Version 3). FHI 360/FANTA, Washington, D.C Retrieved from https://www.fantaproject.org/sites/ default/files/resources/HFIAS_ENG_v3_Aug07.pdf

CSA \& ICF International (2017) Ethiopia Demographic and Health Survey 2016. Central Statistical Authority \& ICF Internation, Addis Ababa and Rockville Retrieved from https://dhsprogram.com/pubs/pdf/FR328/FR328.pdf

Dercon S, Gilligan DO, Hoddinott J, Woldehanna T (2009) The impact of agricultural extension and roads on poverty and consumption growth in fifteen Ethiopian villages. Am J Agric Econ 91(4):1007-1021. https://doi.org/10.1111/j.1467-8276.2 009.01325.x

Do TL, Nguyen TT, Grote U (2019) Nonfarm employment and household food security: Evidence from panel data for rural Cambodia. Food Security 11(3):703-718. https://doi.org/10.1007/s12571-019-00929-8

FAO, IFAD, UNICEF, WFP, \& WHO (2017) The state of food security and nutrition in the world 2017. Building Resilience for Peace and Food Security. FAO, Rome

Glewwe P, Jacoby HG, King EM (2001) Early childhood nutrition and academic achievement: a longitudinal analysis. J Public Econ 81(3):345-368. https://doi.org/10.1016/S0047-2727(00)00118-3

Gole WT, Senbeta F, Tesfaye K, Fite G (2009) Yayu coffee forest biosphere reserve nomination form. Ethiopian MAB National Committee, Addis Ababa

Govereh J, Jayne TS (2003) Cash cropping and food crop productivity: synergies or trade-offs? Agric Econ 28(1):39-50. https:// doi.org/10.1111/j.1574-0862.2003.tb00133.x

Haile MG, Kalkuhl M, Usman MA (2015) Market information and smallholder farmer price expectations. Afr J Agric Res Econ 10(4):297-311

Handa S, Mlay G (2006) Food consumption patterns, seasonality and market access in Mozambique. Dev Southern Afr 23(4): 541-560. https://doi.org/10.1080/03768350600929249

Hirvonen K, Taffesse AS, Worku Hassen I (2016) Seasonality and household diets in Ethiopia. Public Health Nutr 19(10):17231730. https://doi.org/10.1017/S1368980015003237

Immink MDC, Alarcon JA (1993) Household income, food availability, and commercial crop production by smallholder farmers in the western highlands of Guatemala. Econ Dev Cultural Change 41(2):319-342. https://doi.org/10.1086/452013

Islam AHMS, von Braun J, Thorne-Lyman AL, Ahmed AU (2018) Farm diversification and food and nutrition security in Bangladesh: Empirical evidence from nationally representative household panel data. Food Security 10(3):701-720. https://doi.org/10.1007/s12571-018-0806-3

Jacoby HG, Minten B (2009) On measuring the benefits of lower transport costs. Journal of Development Economics 89(1): 28-38. https://doi.org/10.1016/j.jdeveco.2008.06.004

Janssen V (2018) The effect of agricultural commercialization on food security: the case of crop producing households in post-reform Vietnam. Wageningen UR, Wageningen Retrieved from https://edepot.wur.nl/443236

Jemal O, Callo-Concha D, van Noordwijk M (2018) Local agroforestry practices for food and nutrition security of smallholder farm households in southwestern Ethiopia. Sustainability 10(8):2722. https://doi.org/10.3390/su10082722

Jones AD, Ickes SB, Smith LE, Mbuya MN, Chasekwa B, Heidkamp RA et al (2014) World Health Organization infant and young child feeding indicators and their associations with child anthropometry: a synthesis of recent findings. Matern Child Nutr 10(1):1-17. https://doi.org/10.1111/mcn.12070

Kairiza T, Kembo GD (2019) Coping with food and nutrition insecurity in Zimbabwe: does household head gender matter? Agric Food Econ 7(1):24. https://doi.org/10.1186/s40100-019-0144-6

Kanter R, Walls HL, Tak M, Roberts F, Waage J (2015) A conceptual framework for understanding the impacts of agriculture and food system policies on nutrition and health. Food Security 7(4):767-777. https://doi.org/10.1007/s12571-015-0473-6

Knueppel D, Demment M, Kaiser L (2010) Validation of the household food insecurity access scale in rural Tanzania. Public Health Nutrition 13(3):360-367. https://doi.org/10.1017/S1368980009991121

Kuma T, Dereje M, Hirvonen K, Minten B (2018) Cash crops and food security: evidence from Ethiopian smallholder coffee producers. J Dev Stud 55(6):1267-1284. https://doi.org/10.1080/00220388.2018.1425396 
Linderhof $\mathrm{V}$, Janssen $\mathrm{V}$, Achterbosch T (2019) Does agricultural commercialization affect food security: The case of crop-producing households in the regions of post-reform Vietnam? Sustainability 11(5):1263. https://doi.org/10.33 90/su11051263

Magaña-Lemus D, Ishdorj A, Rosson CP, Lara-Álvarez J (2016) Determinants of household food insecurity in Mexico. Agric Food Econ 4(1):10. https://doi.org/10.1186/s40100-016-0054-9

Melgar-Quinonez HR, Zubieta AC, MkNelly B, Nteziyaremye A, Gerardo MFD, Dunford C (2006) Household food insecurity and food expenditure in Bolivia, Burkina Faso, and the Philippines. J Nutr 136(5):1431S-1437S. https://doi.org/10.1093/jn/136. 5.14315

Muthini D, Nzuma J, Nyikal R (2020) Farm production diversity and its association with dietary diversity in Kenya. Food Security 12(5):1107-1120. https://doi.org/10.1007/s12571-020-01030-1

Negash M, Swinnen JF (2013) Biofuels and food security: micro-evidence from Ethiopia. Energy Policy 61:963-976. https://doi. org/10.1016/j.enpol.2013.06.031

Ntakyo PR, van den Berg M (2019) Effect of market production on rural household food consumption: evidence from Uganda. Food Security 11(5):1051-1070. https://doi.org/10.1007/s12571-019-00959-2

Ogutu SO, Gödecke T, Qaim M (2020) Agricultural commercialisation and nutrition in smallholder farm households. J Agric Econ 71(2):534-555. https://doi.org/10.1111/1477-9552.12359

Pierre-Louis JN, Sanjur D, Nesheim MC, Bowman DD, Mohammed HO (2007) Maternal income-generating activities, child care, and child nutrition in Mali. Food Nutr Bull 28(1):67-75. https://doi.org/10.1177/156482650702800108

Pingali PL (1997) From subsistence to commercial production systems: the transformation of Asian agriculture. Am J Agric Econ 79(2):628-634. https://doi.org/10.2307/1244162

Radchenko N, Corral P (2018) Agricultural commercialisation and food security in rural economies: Malawian experience. J Dev Stud 54(2):256-270. https://doi.org/10.1080/00220388.2017.1283014

Rahman A, Mishra S (2020) Does non-farm income affect food security? Evidence from India. J Dev Stud 56(6):1190-1209. https://doi.org/10.1080/00220388.2019.1640871

Ruel MT, Garrett J, Yosef S, Olivier M (2017) Urbanization, food security and nutrition Nutrition and Health in a Developing World, pp 705-735 Springer

Sibhatu KT, Krishna W, Qaim M (2015) Production diversity and dietary diversity in smallholder farm households. Proceed Natl Acad Sci 112(34):10657-10662. https://doi.org/10.1073/pnas.1510982112

Singh S, Jones AD, DeFries RS, Jain M (2020) The association between crop and income diversity and farmer intra-household dietary diversity in India. Food Security 12(2):369-390. https://doi.org/10.1007/s12571-020-01012-3

Stifel D, Minten B (2017) Market access, well-being, and nutrition: evidence from Ethiopia. World Dev 90:229-241. https://doi. org/10.1016/j.worlddev.2016.09.009

Swindale A, Bilinsky P (2006) Household Dietary Diversity Score (HDDS) for measurement of household food access: indicator Guide (Version 2). FHI 360/FANTA, Washington, D.C

Thorne-Lyman AL, Valpiani N, Sun K, Semba RD, Klotz CL, Kraemer K, Akhter N, de Pee S, Moench-Pfanner R, Sari M, Bloem MW (2010) Household dietary diversity and food expenditures are closely linked in rural Bangladesh, increasing the risk of malnutrition due to the financial crisis. J Nutr 140(1):182S-188S. https://doi.org/10.3945/in.109.110809

Thornton PK, Jones PG, Ericksen PJ, Challinor AJ (2011) Agriculture and food systems in sub-Saharan Africa in a $4<$ sup $>^{\circ}</$ sup>C+ world. Phil Trans Royal Soc A 369(1934):117-136. https://doi.org/10.1098/rsta.2010.0246

UNDP. (2012). Africa Human Development Report 2012 Towards a Food Secure Future. Retrieved from http://ageconsearch. umn.edu/record/267636/files/UNDP-Africa\%20HDR-2012-EN.pdf

Usman MA, Gerber N, von Braun J (2019) The impact of drinking water quality and sanitation on child health: evidence from rural Ethiopia. J Dev Stud 55(10):2193-2211. https://doi.org/10.1080/00220388.2018.1493193

Usman MA, Haile MG (2019) Market access, food security and nutrition: evidence from selected sub-Saharan African countries. In: Paper presented at the 6th African Conference of Agricultural Economists: Rising to meet new challenges—Africa's agricultural development beyond 2020 Vision, Abuja, Nigeria

von Braun J (1995) Agricultural commercialization: Impacts on income and nutrition and implications for policy. Food Policy 20(3):187-202. https://doi.org/10.1016/0306-9192(95)00013-5

von Braun J, Kennedy ET (1994) Commercialization of agriculture, economic development, and nutrition. John Hopkins Press, Baltimore

Webb P, Kennedy E (2014) Impacts of agriculture on nutrition: nature of the evidence and research gaps. Food Nutr Bull 35(1):126-132. https://doi.org/10.1177/2F156482651403500113

Wiggins, S., \& Keats, S. (2013). Leaping and learning: linking smallholders to markets in Africa. Available at http://hdl.handle. net $/ 10568 / 35246$

Wood B, Nelson C, Kilic T, Murray S (2013) Up in smoke? Agricultural commercialization, rising food prices and stunting in Malawi (The World Bank Group, Policy Research Working Paper 6650). https://doi.org/10.1596/1813-9450-6650

World Bank (2012) Transforming through infrastructure: infrastructure strategy updates, FY 2012-2015. World Bank, Washington, DC

\section{Publisher's Note}

Springer Nature remains neutral with regard to jurisdictional claims in published maps and institutional affiliations. 